\title{
Must losing taxes on saving be harmful?
}

\author{
Huizinga, Harry; Nielsen, Søren Bo
}

Document Version

Final published version

Publication date:

2004

\section{License \\ CC BY-NC-ND}

Citation for published version (APA):

Huizinga, H., \& Nielsen, S. B. (2004). Must losing taxes on saving be harmful?.

Link to publication in CBS Research Portal

\section{General rights}

Copyright and moral rights for the publications made accessible in the public portal are retained by the authors and/or other copyright owners and it is a condition of accessing publications that users recognise and abide by the legal requirements associated with these rights.

\section{Take down policy}

If you believe that this document breaches copyright please contact us (research.lib@cbs.dk) providing details, and we will remove access to the work immediately and investigate your claim. 


\section{Department of Economics}

Copenhagen Business School

\section{Working paper 15-2004}

MUST LOSING TAXES ON SAVING BE HARMFUL?

Harry Huizinga Søren Bo Nielsen 


\title{
Must losing taxes on saving be harmful?
}

\author{
Harry Huizinga \\ Tilburg University and CEPR \\ and \\ Søren Bo Nielsen \\ Copenhagen Business School, EPRU and CEPR *
}

May 2004

\begin{abstract}
Internationalization offers enhanced opportunities for individuals to place savings abroad and evade domestic saving taxation. This paper asks whether the concomitant loss of saving taxation necessarily is harmful. To this end we construct a model of many symmetric countries in which public goods are financed by taxes on saving and investment. There is international cross-ownership of firms, and countries are assumed to be unable to tax away pure profits. Countries then face an incentive to impose a rather high investment tax also borne by foreigners. In this setting, the loss of the saving tax instrument on account of international tax evasion may prevent the overall saving-investment tax wedge from becoming too high, and hence may be beneficial for moderate preferences for public goods. A world with 'highspending' governments, in contrast, is made worse off by the loss of saving taxes, and hence stands to gain from international cooperation to restore saving taxation.
\end{abstract}

JEL-Classification: H87, H21

Keywords: Capital income taxation, cross-ownership, coordination

${ }^{*}$ Comments from Jonas Agell, Kaare Haagen, and Jay Wilson on an early version of this paper are gratefully acknowledged. The activities of EPRU are financed by a grant from The Danish National Research Foundation. Correspondence to Søren Bo Nielsen, Department of Economics, Copenhagen Business School, Solbjerg Plads 3, DK-2000 Frederiksberg, Denmark; e-mail: sbn.eco@cbs.dk. 


\section{Introduction}

Capital income taxes are generally applied to saving as well as investment. The distinction between saving and investment taxation is immaterial in a (stylized) closed economy, but not in an open economy. Internationally, taxes on saving generally apply to worldwide savings, while investment taxes in principle affect only local investment. Most countries apply both saving and investment taxes, and thus have tax systems that combine residence-based and source-based taxation. Over time, however, countries have found it increasingly difficult to enforce residence-based taxes on saving, as international financial integration offers ample opportunities to avoid such taxation. Continued erosion of residence-based taxation would imply that in the end only source-based capital income taxes remain.

Should we mourn the possible loss of residence-based capital income taxes? Judging from long-standing national and international policy initiatives in this area, we should. Individually and collectively, countries seem to try very hard to repair residence-based capital income taxes. Requirements of banks to report domestic interest payments, for instance, and bilateral commitments to exchange interest payment information all aim to enable the taxation of savings. Multilaterally, discussions at the OECD and in the EU serve the same purpose. The EU introduced a proposal for a common minimum withholding tax on interest already in 1989, followed by a proposal for an exclusive choice between withholding taxation and information exchange in $1998 .^{1}$ More recently, the EU Council of Economics and Finance Ministers reached a political agreement on a saving tax directive with an emphasis on the international exchange of information in January 2003 (see below).

This paper evaluates the welfare consequences of a loss of the saving tax instrument, and of its mirror-image of resurrecting the saving tax instrument through international cooperation. Cooperation is assumed to go only so far as to enable each country to impose

\footnotetext{
${ }^{1}$ For analyses of withholding taxes and information exchange as a means to secure the taxation of international interest flows, see Huizinga and Nielsen (2003) and Keen and Ligthart (2002).
} 
a saving tax. This is the essence of the international cooperation in the form of exchange of information to be implemented in the EU. Tax rates thus are set non-cooperatively regardless of whether the saving tax is available. In this setting, we show that the loss of the saving tax paradoxically may improve welfare. The reason is that international share ownership may lead to a saving-investment tax wedge, i.e. the wedge between the required return to investment and the net return to saving, that is too high in the noncooperative equilibrium with saving taxation. This reflects that the investment tax is set too high in an effort to tax the foreign owners of domestic firms. The loss of the saving tax instrument will then reduce the overall saving-investment tax wedge and may in fact bring it closer to the saving-investment tax wedge that arises with full international cooperation (also in the area of tax rates). In this scenario, international cooperation to restore saving taxation may reduce welfare and hence would be perverse. This would be the case with 'low-spending' governments with moderate tastes for public goods. In contrast, for 'high-spending' governments with strong preferences for public goods the restoration of the saving tax instrument would increase welfare.

These ambiguous welfare consequences reflect several conflicting international externalities associated with especially national investment tax policies. First, a higher investment tax has a direct, negative impact on foreign welfare to the extent that the investment tax is borne by foreign shareholders. This we term a tax exporting externality. Second, a higher investment tax gives rise to higher foreign saving exactly because foreign after-tax profit income is foreseen to decline. Higher foreign saving raises revenues abroad from saving taxation. This second saving externality is clearly a positive externality (as long as the saving tax abroad is positive). Finally, a third externality may arise, as the higher investment tax at home tends to lower the world interest rate. On the one hand, this stimulates foreign investment, adding to foreign investment tax revenues; on the other, it reduces foreign saving, decreasing saving tax revenues. With both investment and saving taxes present abroad, in general this third tax base externality has an ambiguous net effect on foreign welfare. 
Notice that the second and third externalities will be more important, the higher is the need for tax revenues to finance public goods provision (and therefore the higher are investment and saving tax rates). Hence, for low preferences for public goods saving and investment taxes are low enough for the first externality to dominate, so that capital income taxation with both investment and saving taxes produces too high a saving-investment tax wedge. Under these circumstances, losing the latter instrument may improve welfare. Contrary to this, for high preferences for public goods the first externality will be dominated by the second and third externalities. Indeed, in that case the combined externality on other countries from a higher tax wedge in one country will be positive, so that the saving-investment tax wedge with both tax instruments will be too low relative to a fully coordinated tax policy. Accordingly, losing the saving tax will make matters worse and reduce welfare.

Important for our argument for an ambiguous welfare effect of restoring saving taxation is foreign ownership of capital in any given country. As seen in Table 1 in the Appendix, average foreign ownership of assets relative to GDP in the EU for both nontraded assets (in the form of direct investments) and for traded assets (in the form of portfolio investments) is already quite extensive at 14 and 16 percent, respectively. In our stylized model, governments only raise taxes to finance public expenditures. More generally, of course, governments may require high capital income tax revenues to finance a high level of redistribution. A group of countries thus may equally benefit from the restoration of the saving tax in defense of the welfare state.

As indicated, efforts to shore up the taxation of savings in the EU go back to 1989. Only recently, however, has there been substantive progress in this area. In November 2000, the Council of Economics and Finance ministers agreed in principle that the EU should adopt a generalized system of international exchange of information on interest payments by the year 2010. Until then, Austria, Belgium, and Luxembourg would be free to levy a minimum withholding tax instead. In January 2003, the Council reached political agreement on a savings directive as part of a larger 'Tax Package' and committed 
itself to formally adopt the Package before the European Council in March 2003. In the end, the Package was adopted in June 2003. The proposed savings directive makes the international exchange of information the standard of cooperation, even though three EU member states (Austria, Belgium and Luxembourg) are allowed to impose non-resident interest withholding taxes instead (at a rate of 15 percent from January 1, 2005, to be raised to 20 percent on January 1, 2008, and to 35 percent on January 1, 2011). ${ }^{2}$

What has caused the recent drive in the EU towards enhanced cooperation to restore the taxation of savings? Over the last two and a half decades, two relevant trends can be identified. First, capital markets have become more deeply integrated leading to a higher degree of international capital mobility. The key reasons for this are that national authorities have discarded with capital controls, and that information technology has advanced greatly. As a result, evading saving taxes by placing funds abroad now is easier than ever. Second, many European countries seemingly have expanded their total public outlays in this period. As evidence of this, the average total tax burden in EU (total tax intake relative to GDP) has increased from 34 pct. in 1975 to more than 41 pct. in 2000, as can be seen in Table 2 in the Appendix. ${ }^{3}$ This development suggests that the need to secure revenue from also saving taxation has been on the rise. The overall increase in the size of government may well reflect that countries have become richer in the meantime (presuming an income elasticity of government expenditures/transfers in excess of unity)

\footnotetext{
${ }^{2}$ Belgium, Luxembourg and Austria will subsequently implement automatic exchange of information, if and when the EU enters into an agreement with Switzerland, Liechtenstein, San Marino, Monaco and Andorra to exchange information, and if and when the United States similarly commits itself to exchange information. At the time of this writing (April 2004), the Commission has presented a draft agreement only with Switzerland that will only sign after satisfactory results in the other bilateral negotiations have been achieved. For more information on the Tax Package and related Commission activities, see Commissioner Bolkestein's Speech/04/136 and the press release IP/03/787 under http://europa.eu.int/taxation_customs.

${ }^{3}$ The table demonstrates that the overall increase reflects different trends for different EU countries. Some countries had a steadily increasing tax burden during the period; for other countries the expansion of the public sector seems to have stopped in the mid-1980s; finally, for some countries may be no clear trend in the overall tax burden.
} 
and perhaps that in some countries governments with more of a socialist inclination have been in office.

Several authors have previously examined the optimal capital income taxation in a small open economy, without evaluating the welfare consequences of the loss of a particular tax instrument. Gordon (1986), Frenkel et al. (1991) and others show that a small economy optimally does not levy a source-based investment tax, if a full tax instrument set, including unlimited profit and labor taxes, is available. Source-based investment taxes, however, are generally optimally applied in the absence of a profit tax. Huizinga and Nielsen (1997) in particular examine how the optimal saving and investment tax mix depends on the feasibility of profit taxation, and on the extent of foreign ownership of domestic firms. Investment and profit taxes are relatively advantageous with foreign ownership, and may even serve to finance negative saving taxes (so as to transfer resources to domestic residents).

Several contributions have also examined the need for international coordination of capital income taxes. ${ }^{4}$ Razin and Sadka (1991) consider a model, in which labor and capital are inputs into a production function with constant returns to scale. In this setting, two countries have no reason to coordinate either saving or investment taxes, if they take the world interest rate as given. Bucovetsky and Wilson (1991) consider labor, saving and investment taxes in a similar model, but let the world interest rate be endogenous. They show that countries then equally have no need to coordinate co-existing saving and investment taxes. Huizinga and Nielsen (2002) extend this work to include profit taxation and foreign ownership in a model with many symmetric countries. With incomplete profit taxation and some foreign ownership, there generally exists a need to coordinate the saving-investment tax wedge upwards or downwards, depending on the availability of tax instruments and the strength of government preferences for public goods. The present paper instead assumes throughout that countries do not coordinate their tax rates, and then considers whether welfare is higher with or without an effective

\footnotetext{
${ }^{4}$ See also OECD (1991), the Ruding Report (1992), and Keen (1993).
} 
saving tax instrument.

Our paper is structured as follows. Section 2 considers optimal tax policy from the perspective of a single small open economy. This is done for the case where investment and saving taxes are both operative, and also for the case where only an investment tax is available. Section 3 examines the optimal tax policy for a similar closed economy that imposes a single tax wedge between the gross return to investment and the net return to saving. Optimal tax policy in the closed economy corresponds to the fully coordinated tax policy in the world of small open economies. Section 4 contains the three possible pairwise comparisons of tax wedges across the three tax regimes dealt with in sections 2 and 3. These tax wedge comparisons are a prerequisite for the welfare comparison between the two noncooperative regimes with and without the saving tax in Section 5. Section 6 concludes.

\section{Tax policy in the small open economy}

This section examines the optimal capital income tax policy from the perspective of a small open economy. After outlining the basic model, we in turn consider the cases where saving and investment taxes are both available, and where only investment taxes are available.

\subsection{The basic model}

The basic model corresponds to Huizinga and Nielsen (1997) with the exceptions that the present model takes the supply of public goods to be endogenous, while there is no profit taxation nor any possibility of government lump sum transfers to domestic residents. ${ }^{5}$ The small open economy is one of many identical economies in the world economy. The economy exists for two periods, and takes the world interest rate, $r$, as given. Each

\footnotetext{
${ }^{5}$ Introducing a less than full profit tax will not alter any of our qualitative conclusions.
} 
country's representative agent receives an endowment, $Y$, of a single good in the first period. This endowment is allocated between first period consumption, $C_{1}$, and saving, $S$. In the first period, firms make investments, $K$, that are only productive in the second period. In the second period, households spend their net-of-tax return from saving and profit income to consume $C_{2}$.

Consumers also enjoy a public good, $G$, provided by the government in the second period. To finance this public good, the government can impose a saving tax at the rate $u$, and an investment tax at the rate $v$, both payable in the second period. There are pure profits from production, because there is some factor of production, e.g. land or entrepreneurial services, in inelastic supply, or alternatively there are decreasing returns to scale regarding capital investments. As stated above, we assume that these profits cannot be taxed. There are no restrictions on the sizes or signs of the saving and investment taxes, $u$ and $v$. Finally, we assume that the representative firm and thus its profit stream are in part foreign-owned. In particular, a share $\alpha \geq 0$ of each country's firms is owned by foreigners. Conversely, domestic citizens own a total share of $\alpha^{*}$ of foreign firms.

Firms produce an output $F(K)$ in the second period, where the production function $F$ is assumed to be strictly concave. Firms' after-tax profits are $[F(K)-(1+r+v) K]$, where $1+r+v$ is the user cost of capital. Profit maximization on the part of firms yields the following optimal investment rule,

$$
F^{\prime}(K)=1+r+v
$$

Households in turn face the following two-period budget constraint,

$$
\begin{gathered}
C_{2}=\left(Y-C_{1}\right)(1+r-u)+(1-\alpha)[F(K)-(1+r+v) K] \\
+\alpha^{*}\left[F\left(K^{*}\right)-\left(1+r+v^{*}\right) K^{*}\right]
\end{gathered}
$$

where stars denote foreign variables. ${ }^{6}$

\footnotetext{
${ }^{6}$ Note that profits earned abroad accruing to domestic residents are neither taxed abroad nor at home. Again, partial taxation of profits would not affect our qualitative results. Further note that full symmetry in the world economy entails that $\alpha^{*}=\alpha$.
} 
Consumers derive utility from private consumption in both periods and from the public good, $G$. Lifetime utility is assumed to be additively separable, and is written as $U\left(C_{1}, C_{2}\right)+V(G)$. The first order condition regarding the private consumption choice is as follows,

$$
U_{1}=U_{2}(1+r-u)
$$

The budget constraint of the government stipulates that overall tax revenues equal the provision of the public good, $G$, as follows,

$$
0<G=u S+v K
$$

Tax policy is set so as to maximize the utility of the representative agent. Formally, the government faces the problem of choosing tax rates $u$ and $v$ plus public good provision $G$ so as to maximize the following Lagrangean expression,

$$
\begin{aligned}
L= & U\left(C_{1},\left(Y-C_{1}\right)(1+r-u)+(1-\alpha)[F(K)-(1+r+v) K]+\right. \\
& \left.\alpha^{*}\left[F\left(K^{*}\right)-\left(1+r+v^{*}\right) K^{*}\right]\right)+V(G)+\lambda(u S+v K-G)
\end{aligned}
$$

The maximization is carried out respecting constraints (2.1) and (2.3); $\lambda$ is a Lagrange multiplier associated with the government budget constraint (2.4). The first order conditions regarding the tax rates $u$ and $v$ and the volume of public goods $G$ can be stated as follows,

$$
\begin{gathered}
-U_{2}+\lambda\left(1-u e_{u}\right)=0 \\
-U_{2}(1-\alpha)+\lambda\left[1+(1-\alpha) u p-e_{v} v\right]=0 \\
V^{\prime}(G)-\lambda=0
\end{gathered}
$$

where $e_{v}=-(d K / d r) / K$ is the semi-elasticity of investment with respect to the investment $\operatorname{tax} v, e_{u}=-(d S / d u) / S$ is the uncompensated semi-elasticity of saving with respect to the saving tax $u$, and $p$ denotes the propensity to consume in the first period out of second period income. It can be seen that $e_{u}^{c}=e_{u}+p>0$ is the compensated semielasticity of saving with respect to the saving tax, $u$. The uncompensated semi-elasticity $e_{u}$ will also be taken to be positive in what follows. 
The first order conditions (2.6)-(2.8) characterize tax policy in the cases where both capital tax instruments are available, or where the saving tax is not part of the instrument set (in which case (2.6) is not relevant). Absent cooperation, a world of small countries is engaged in a non-cooperative policy game; more precisely, we can define the noncooperative capital income tax equilibrium in the world of small economies as follows:

Non-cooperative tax equilibrium: A Nash equilibrium of the capital income tax game is a series of tax rates $u_{i}, v_{i}$ for each single country that maximizes welfare in country $i$ given tax rates in all other countries $\left(u_{-i}, v_{-i}\right)$.

With all countries symmetric, we focus on the symmetric non-cooperative tax equilibrium. Next, we briefly discuss the optimal tax policy for the two cases with and without saving taxation on the assumption of a positive cross-ownership of firms, i.e. a positive $\alpha$. In section 5, we indicate how the discussion changes if there is no foreign ownership, $\alpha=0$.

\section{$2.2 \quad$ All tax instruments available}

From conditions (2.6)-(2.8), the optimal saving tax, $u$, can be seen to be either positive or negative, while the investment tax, $v$, is always non-negative. The exact sizes of the capital income taxes depend on the desired level of public goods. Three separate cases, increasing in the desired level of public goods provision, can be distinguished. In case i), the demand for public goods is so weak that the investment tax, acting as a substitute profit tax, is used to finance both public goods provision and a saving subsidy, while the marginal cost of public funds (MCPF), measured as $\eta \equiv \lambda / U_{2}$, is below unity. In a borderline case ii), the saving tax rate, $u$, is just equal to zero, and the MCPF equals unity, while the investment tax rate is at its national income maximizing value of $v=\alpha / e_{v}$. In case iii), finally, both saving and investment taxes are positive with the MCPF exceeding one. 


\subsection{Only investment taxation}

Absent the saving tax, optimal tax policy is found from equations (2.7) and (2.8) with $u$ set equal to zero in (2.7). The investment tax, $v$, can be written as $v=[1-(1-\alpha) / \eta] / e_{v}$. This expression for $v$ is positive, as the investment tax is the only avenue to finance public goods provision.

\section{Tax policy in the closed economy}

In this section, we consider the optimal capital income tax policy in a closed economy. The closed economy is taken to be identical to the single small open economy considered before. Obviously, savings and investment in the closed economy have to be equal, i.e. $S=K$. The closed economy's tax policy is of interest, as it corresponds to the cooperative tax policy in a world of many identical small open economies. This section therefore sets the stage for the subsequent welfare evaluation of different non-cooperative tax regimes in sections 4 and $5 .{ }^{7}$ In the closed economy, the tax authority has a single tax instrument, $x$, to introduce a wedge between the gross return to investment and the net return to saving. The $\operatorname{tax} x$ can be thought to be levied on investment, so that the net return to saving and the market rate of interest are $r$, while $r+x$ is the required return to investment.

Profit maximization on the part of firms now yields the following investment rule,

$$
F^{\prime}(K)=1+r+x
$$

The budget constraints for private agents and the government are rewritten as,

$$
C_{2}=\left(Y-C_{1}\right)(1+r)+[F(K)-(1+r+x) K]
$$

\footnotetext{
${ }^{7}$ By focusing on symmetric countries, we concentrate on average externalities among countries in noncooperative tax policy equilibria. The implications of asymmetry for tax competition have been studied by Bucovetsky (1991). Tax coordination can also be asymmetric in that only part of the countries in the world participate. See, for instance, Mendoza (2002) for a discussion of European tax harmonization in a larger world.
} 


$$
0<G=x K
$$

Again, the government chooses tax policy and public goods provision, i.e. $x$ and $G$, so as to maximize the utility of the representative agent, respecting equations (3.1)-(3.3). The optimality conditions with respect to $x$ and $G$ are as follows, ${ }^{8}$

$$
\begin{gathered}
-U_{2}+\lambda\left(1-x e_{s}\right)=0 \\
V^{\prime}(G)-\lambda=0
\end{gathered}
$$

In these expressions, $e_{s} \equiv-(d S / d x) / S$ is the semi-elasticity of saving with respect to the single tax wedge, $x$, accounting for any endogenous change in the interest rate. The semi-elasticity $e_{s}$ can be expressed as follows,

$$
e_{s}=-p-\frac{d r}{d x}\left(e_{u}+p\right)
$$

At the same time, the saving-investment balance implies that $d r / d x$ can be found as,

$$
\frac{d r}{d x}=\frac{e_{s}-e_{v}}{e_{v}}
$$

so that $e_{s}$ can be written as,

$$
e_{s}=\frac{e_{v} e_{u}}{e_{v}+p+e_{u}}
$$

The optimality condition (3.4) takes into account that, unlike in the small open economy, the capital income tax, $x$, affects the interest rate, $r$. The change in the interest rate independently affects economic behavior and also overall capital income tax revenues. Condition (3.4) also differs from the first order condition for the investment tax in the small open economy (2.7) in that in the closed economy the incidence of the investment tax is entirely on own residents.

\footnotetext{
${ }^{8}$ It can easily be checked that the first order condition with respect to a tax on saving rather than investment is identical to (3.4).
} 


\section{Tax wedges in non-cooperative and cooperative regimes}

So far, we have described tax policies for different instrument sets in the small open economy, and in the closed economy. The two regimes with and without the saving tax in the small open economy, the saving-tax $(s)$ and the no-saving-tax $(n s)$ regimes, are non-cooperative regimes in that tax rates are set non-cooperatively. Contrary to this, tax policy in the closed economy corresponds to a cooperative regime $(c)$ with fully coordinated tax policies across the world's economies. These three tax regimes are all fully characterized by the obtained saving-investment tax wedge (and the resulting revenue subsequently spent on public goods).

Our main interest in this paper is to compare the obtained welfare levels in the two non-cooperative tax regimes for the small open economy, with and without the saving tax. This is done in Section 5. To see how such a welfare comparison can be made, suppose that both the $s$ and $n s$ regimes yield saving-investment tax wedges above the cooperative tax wedge in the $c$ regime. The $n s$ regime is then preferred to the $s$ regime, if the tax wedge in the $n s$ regime is smaller than in the $s$ regime and thereby closer to the cooperative tax wedge, i.e. if $x^{c}<x^{n s}<x^{s}$. As another example, if the tax wedges in the two non-cooperative regimes are both smaller than the cooperative tax wedge and $x^{c}>x^{s}>x^{n s}$, then the saving-tax regime is preferred.

Hence, a welfare comparison across non-cooperative tax regimes requires that we first rank tax wedges across all three regimes; consequently, we carry out three pairwise tax wedge comparisons: (i) between the $s$ and $c$ regimes; (ii) between the $n s$ and $c$ regimes; and (iii) between the $s$ and $n s$ regimes.

Non-cooperation with a saving tax vs. cooperation, $s$ vs. $c$

By definition, starting from the non-cooperative tax equilibrium in the $s$ regime a unilateral increase in either the saving or the investment tax will be perceived by the country in question to have no impact on national welfare. Nonetheless, a common 
increase in the saving-investment tax wedge in all countries generally will have a non-zero impact on each country's welfare. If an across-the-board tax wedge increase raises national welfare, then we can conclude that the tax wedge in the non-cooperative equilibrium was too low, and vice versa.

What are the underlying reasons that non-cooperative tax policy may not be optimal from the world's perspective? Three different externalities of national income tax policy can in fact be identified. To illustrate these, let us consider the impact on a domestic economy, if all other countries increase their investment tax in unison. An expression for this welfare effect, denoted $d W / d v^{*}$, is found by direct differentiation of the Lagrangean in $(2.5)$ as follows,

$$
\frac{d W}{d v^{*}}=-U_{2} \alpha K+\lambda u p \alpha K+\frac{d W}{d r} \frac{d r}{d v^{*}}
$$

The three terms on the right hand side of (4.1) correspond to the three externalities that can be distinguished. The first externality, a tax exporting externality, simply reflects that with cross-ownership higher foreign investment taxes directly reduce domestic after-tax profit income. This is obviously a negative externality. The second externality, a saving externality, arises as higher foreign investment taxes engender higher domestic saving exactly because domestic after-tax profit income (to be received in the second period) is lower. The higher domestic savings are taxed domestically at a rate $u$, adding to domestic saving tax revenues. This second externality thus is positive (if $u$ is positive). Finally, a third externality generally arises, as higher foreign investment taxes tend to lower the world interest rate. This stimulates domestic investment (adding to domestic investment tax revenues), but reduces domestic saving (lowering domestic saving tax revenues). With investment and saving taxes present, this third tax base externality in general has an ambiguous net effect on domestic welfare.

To learn the net effect of these various externalities in the saving-tax regime, we employ eq. (3.4) to see how a common tax wedge increase affects national welfare levels. Specifically, a common increase in the (investment) tax rate lowers utility from private goods by $U_{2} K$, and it raises utility from public goods by $\lambda\left(1-x e_{s}\right) K$. Taken together, 
we find that $(d W / d x) / K=-U_{2}+\lambda\left(1-x e_{s}\right)$. In this expression, $U_{2}, \lambda, x, K$ and $e_{s}$ are all evaluated at the non-cooperative tax wedge. To see whether $(d W / d x) / K$ is positive or negative, we can arbitrarily assume that the increase in the overall tax wedge from the non-cooperative level comes about through a higher investment tax. This allows us to retrieve the following expression for $U_{2}$ from $(2.7)$,

$$
U_{2}=\lambda \frac{1+(1-\alpha) u p-e_{v} v}{1-\alpha}
$$

which enables us to write the net gain from a higher investment tax as

$$
(d W / d x) / K=\lambda\left[-\frac{1+(1-\alpha) u p-e_{v} v}{1-\alpha}+1-x e_{s}\right]
$$

From (2.6) and (2.7) and the equality $x=u+v$, we can next derive the following expressions for $u$ and $v$ as functions of $x$,

$$
u=\frac{e_{v} x-\alpha}{e_{v}+e_{u}^{c}(1-\alpha)}, \quad v=\frac{e_{u}^{c}(1-\alpha) x+\alpha}{e_{v}+e_{u}^{c}(1-\alpha)}
$$

Also using the formula for $e_{s}$ in (3.8), we now can obtain after some manipulation,

$$
(d W / d x) / K=\frac{\alpha \lambda e_{u}}{\left(e_{v}+e_{u}^{c}\right)\left(e_{v}+e_{u}^{c}(1-\alpha)\right)}\left[-\left(e_{v}+e_{u}^{c}\right)+e_{v} e_{u}^{c} x\right]
$$

With positive cross-ownership of firms (i.e. $\alpha>0$ ), it is easily seen that the overall tax wedge increase from the non-cooperative level is welfare-enhancing if, ${ }^{9}$

$$
x>\frac{1}{e_{u}^{c}}+\frac{1}{e_{v}}
$$

Thus, if the non-cooperative tax wedge in the saving-tax regime already exceeds the righthand-side of (4.3), then a further increase in the tax wedge is welfare-enhancing, and vice versa. These are also the conditions for the non-cooperative tax wedge in the saving-tax regime to be less than the cooperative tax wedge, and vice versa. We state this section's main finding as

RESULT 1. If the saving-investment tax wedge in the non-cooperative regime with both saving and investment taxes available exceeds $1 / e_{u}^{c}+1 / e_{v}$, then raising it in all countries

\footnotetext{
${ }^{9}$ We deal with the case of $\alpha=0$ in subsection 5.1 below.
} 
will enhance welfare. If the opposite inequality holds, lowering the wedge will be welfareimproving.

Result 1 indicates that the combined negative externalities (the tax exporting externality and the saving part of the tax base externality) dominate for low values of the saving-investment tax wedge - and hence low or moderate preferences for public goods. Conversely, the positive externalities (the saving externality and the investment part of the tax base externality) dominate for high values of the tax wedge and thus strong preferences for public goods. This is intuitive, as the second externality above is stronger, the larger is the tax wedge and, in particular, the tax on saving (viz. the variable $u$ in the second term in (4.1)).

Non-cooperation without a saving tax vs. cooperation, ns vs. $c$

Next, we compare the tax wedges and welfare levels in the non-cooperative no-savingtax regime and the cooperative regime. We proceed in a manner completely parallel to above. An increase in the investment tax in all countries by one unit in the noncooperative regime again entails a loss of utility from private goods of $U_{2} K$ and a gain in utility from public goods of $\lambda\left(1-x e_{s}\right) K$. From the first order condition (2.7) with $u=0$, we can now express $U_{2}$ as,

$$
U_{2}=\lambda \frac{1-e_{v} v}{1-\alpha}
$$

Noting also that $v=x$ in the absence of saving taxation, we can finally express the welfare gain from the uniform international investment tax increase as,

$$
(d W / d x) / K=\frac{\lambda}{\left(e_{v}+e_{u}^{c}\right)(1-\alpha)}\left[-\alpha\left(e_{v}+e_{u}^{c}\right)+e_{v} x\left(e_{v}+p+\alpha e_{u}\right)\right]
$$

Thus, a joint increase in investment taxes will raise welfare in all countries if,

$$
x>\frac{\alpha\left(e_{v}+e_{u}^{c}\right)}{e_{v}\left(e_{v}+p+\alpha e_{u}\right)}
$$

For later use, we state this as Result 2, 
RESULT 2. An increase in the saving-investment tax wedge from the non-cooperative tax equilibrium in the no-saving-tax regime is welfare-enhancing, iff the wedge exceeds $\alpha\left(e_{v}+e_{u}^{c}\right) /\left[e_{v}\left(e_{v}+p+\alpha e_{u}\right)\right]$.

The intuition for this result is as follows. For weak demand for public goods, the investment tax will be small. An increase in the tax abroad will then lower welfare in the country under consideration, because its residents partly bear the burden of the tax. This negative externality cannot be offset by the positive externality associated with a lower interest rate worldwide and hence higher investment and investment tax revenues at home, exactly because the investment tax is only small. Hence, for weak preferences for public goods, the non-cooperative tax wedge exceeds the cooperative one. For strong enough preferences for public goods, however, the investment tax is high enough for the net spillover of an even higher investment tax to be positive. In this instance, the cooperative tax wedge exceeds the non-cooperative one.

Non-cooperation with a saving tax vs. non-cooperation without a saving tax, s vs. ns

The last tax wedge comparison involves the two non-cooperative capital tax regimes. Specifically, we ask when the saving-investment tax wedge in the saving-tax regime exceeds the tax wedge in the no-saving-tax regime. Equivalently, we could ask when the loss of the saving tax leads to a reduction in the saving-investment tax wedge. The answer to these questions is straightforward.

To start, if preferences for public goods happen to lead countries to select a positive investment tax equal to $\alpha / e_{v}$ and a zero saving tax in the saving-tax regime, then the loss of the saving tax is inconsequential. If preferences for public goods are somewhat stronger, each country in the saving-tax regime selects an investment tax greater than $\alpha / e_{v}$ along with a positive saving tax, resulting in a total saving-investment tax wedge above $\alpha / e_{v}$. In this case, the loss of the saving tax naturally leads to a rise in the investment tax as the remaining capital tax instrument, but not enough to fully reestablish the tax wedge in the saving-tax regime, since the perceived marginal cost of public funds rises. The overall 
tax wedge thus is reduced following the loss of the saving tax instrument Conversely, if the no-saving-tax regime entails an investment tax lower than $\alpha / e_{v}$ coupled with a saving subsidy (a negative saving tax), then the elimination of the saving tax will only partly be offset by a drop in the investment tax so that the overall saving-investment wedge increases. We summarize this discussion as follows,

RESULT 3. The saving-investment tax wedge in the non-cooperative tax equilibrium with both saving and investment taxes will exceed the wedge in the non-cooperative tax equilibrium without saving taxation iff $x>\alpha / e_{v}$.

\section{When is the loss of saving taxes welfare-enhancing?}

We are now ready to examine when the loss of the saving tax instrument actually increases welfare in a setting of non-cooperative capital income taxation. This is the case, if the saving-investment tax wedge under non-cooperative taxation in the no-saving-tax regime better approximates the cooperative tax wedge than the wedge under non-cooperative taxation in the saving-tax regime.

In our discussion, we maintain that tax wedges of different sizes can come about - in the same tax regime - as a result of a varying strength of preferences for public goods. Straightforwardly, stronger preferences for public goods give rise to a larger tax wedge and a higher supply of public goods in any particular tax regime. This section then attempts to isolate for what preferences for public goods the loss of the saving tax instrument actually is welfare-improving. Regarding the strength of the demand for public goods, we can generally distinguish four different scenarios referring to Results 1 to 3 of the previous section.

First, preferences for public goods can be very weak so that in the non-cooperative saving-tax regime the saving tax in fact is non-positive. In this case, we have $x^{c}<x^{s} \leq$ $x^{n s}$, i.e. the tax wedge in the saving-tax regime is greater than in the cooperative tax 
wedge regime, but smaller than in the no-saving-tax regime. In the borderline case where the saving tax actually equals zero, we have $x^{n s}=x^{s}$. Obviously, the no-saving-tax regime cannot be preferred to the saving-tax regime in this case.

Second, there can be very strong preferences for public goods so that the tax wedge in the non-cooperative saving-tax regime is not greater than under cooperation. This means that $x^{s} \geq 1 / e_{u}^{c}+1 / e_{v}$. In addition, it follows that $x^{s}>\alpha / e_{v}$, so that we obtain the ranking $x^{n s}<x^{s} \leq x^{c}$. The non-cooperative tax wedge in the no-saving-tax regime is again farthest from the cooperative one, implying that also in this second case the saving-tax regime is preferred to the no-saving-tax regime.

The third case has moderate preferences for public goods, entailing that in the savingtax regime the saving tax will be positive, but not much greater than zero. At the same time, this case is characterized by the non-cooperative tax wedge in the no-saving-tax regime being greater than or equal to the cooperative tax wedge. This implies that the inequality $\alpha / e_{v}<x^{n s} \leq \alpha\left(e_{v}+e_{u}^{c}\right) /\left[e_{v}\left(e_{v}+p+\alpha e_{u}\right)\right]$ defines the third case. Now we obtain from Results 1 to 3 that $x^{c} \leq x^{n s}<x^{s}$, so that the non-cooperative tax regime without saving taxation is bound to produce higher welfare than the non-cooperative regime with both capital income taxes present.

The fourth and final case lies between the third and the second cases, in that preferences for public goods generally are stronger than in the former case, yet weaker than in the latter. The inequality between tax wedges in the fourth case is $x^{n s}<x^{c}<x^{s}$ so that it is difficult to conclude which of the two non-cooperative tax regimes produces higher welfare. Somewhat imprecisely, we can invoke a continuity of the tax wedge in the strength of preferences for public goods, and state that if preferences for public goods are close to the range in the third case above, the non-cooperative tax equilibrium without saving taxation should still be the preferred one. Conversely, if preferences for public goods are almost as strong as required in the second case above, then maintaining saving taxation is preferred.

To be more precise, we can write preferences for public goods as $\nu H(G)$, so that the 
parameter $\nu$ functions as an indicator of the strength of preferences for these goods. Then we can vary $\nu$ systematically from 0 to $\infty$. One possibility then is that we start out in the first regime and then successively move into the third, the fourth, and finally the second regime described above. Depending on functional forms and in particular how the various semi-elasticities vary with tax rates, the picture could be more complicated than this in that the latter three regimes could be encountered more than once, as $\nu$ progresses. However, the saving-investment tax wedge perceived to maximize revenue in the non-cooperative regime with saving taxation will always lie in the second regime, ${ }^{10}$ and the same therefore goes for some neighborhood around it (in particular to the left of it). In addition, there will always be a neighborhood of tax wedges to the right of $\alpha / e_{v}$ (where the saving tax part is only slightly bigger than zero) belonging to the third regime.

To conclude, the message from this discussion is that losing saving taxes will not lower welfare, if they are positive but close enough to zero. We state this insight as a Proposition:

PROPOSITION. If preferences for public goods are moderate, such that the non-cooperative equilibrium with both saving and investment taxation has a positive, but small saving tax, then the loss of saving taxation will be welfare-enhancing. Conversely, if preferences for public goods are either weaker, so that the non-cooperative equilibrium with both capital income taxes has a saving subsidy, or stronger, so that the saving tax will be high, then the loss of the saving tax will lower welfare.

To reiterate, it is the temptation on the part of governments to capture profits otherwise accruing to foreigners that leads to overtaxation of capital income in the saving-tax regime, provided that preferences for public goods are not too strong. The elimination of the saving tax then reduces this excess taxation, and thus can be welfare-enhancing.

\footnotetext{
${ }^{10} \mathrm{It}$ is easily seen that the revenue maximizing tax wedge $\bar{x}^{s}$ is given by $1 / e_{u}+1 / e_{v}+p(1-\alpha) /\left(e_{u} e_{v}\right)$ and satisfies (4.3).
} 


\subsection{Alternative assumptions regarding foreign ownership and profit taxation}

Our analysis so far has been carried out under the assumptions that there is some crossownership of firms and no profit tax. For completeness, we briefly consider the additional cases where either all firms in every country are fully domestically owned, or complete profit taxation is possible.

With full domestic ownership, there are no cross-country profit flows. Non-cooperative capital income tax policy in the saving-tax regime then corresponds to the coordinated policy stance (and to tax policy in the parallel closed economy). ${ }^{11}$ Hence, there is no scope for policy coordination, and losing the saving tax is therefore bound to lower welfare. This insight is supported by equation (4.2) which provides the welfare effect of moving the capital income tax policy away from the non-cooperative equilibrium policy with both capital income tax instruments available. If $\alpha=0$ is inserted into (4.2), a marginal tax change has zero welfare consequences so that indeed there is no scope for policy coordination. To see this, note that with no cross-ownership of firms the first two of the three externalities reflected in (4.1) immediately vanish. The same turns out to hold for the third one, since the associated positive (negative) spillovers on foreign investment (saving) tax bases exactly offset. ${ }^{12}$

Next, we consider the possibility of profit taxation. It can be seen that introducing a partial taxation of profits, i.e. a profit tax of less than 100 percent, will not affect any of our results. An incomplete profit tax combined with foreign ownership of firms preserves cross-border profit flows, and the operation of the tax exportation, saving, and tax base externalities remain as exposited in section 4. Only a complete profit tax of 100 percent, that puts an end to cross-border profit flows, will change the picture. Indeed,

\footnotetext{
${ }^{11}$ This is proved in Prop. 2 in Huizinga and Nielsen (2002).

${ }^{12}$ Without foreign firm ownership, the setting is essentially the same as in the paper by Bucovetsky and Wilson (1991). These authors, as mentioned in the introduction, find no scope for capital income tax coordination when both saving and investment taxes are available.
} 
with complete profit taxation the investment tax will not be used, and only saving taxes remain, if feasible. Losing the saving tax can only be harmful in such circumstances. ${ }^{13}$

\subsection{Discussion}

The main result of this paper is that, paradoxically, losing the saving tax instrument in the international economy may improve welfare and, vice versa, restoring a lost saving taxation could lower welfare. The key reasons for this result are a non-cooperative setting of taxes in individual countries, some foreign ownership of firms, and an incomplete taxation of pure profits. Given the considerable efforts that the European Commission and, to some extent, individual Member States have put into the saving taxation area, it would be nice if on the basis of the analysis in this paper we could firmly conclude whether these efforts are laudable or ill-guided. It seems to us, however, that we should contend ourselves more modestly with pointing out the possible paradox and with suggesting that the issue be further analysed in future work.

The reasons for this are two-fold. First, within our framework it is not easy to determine exactly which of the possible cases applies to EU countries at the moment. Second, in order to make a stronger judgement, a number of additional and complicating factors would have to be taken into account.

As to the first point, we have identified a possibly welfare-enhancing loss of saving taxation in case of moderate preferences for public goods. More precisely, this occurs for a range of preferences for public goods corresponding to a saving-investment tax wedge in the no-saving-tax regime, $x^{n s}$, greater than or equal to $\alpha / e_{v}$, but at the same time not much greater than $\alpha\left(e_{v}+e_{u}^{c}\right) /\left(e_{v}+p+\alpha e_{u}\right)$. In principle, one could compute actual saving-investment tax wedges in EU countries, interprete them as optimal choices given that saving taxation is not entirely feasible at present, and then compare them to the above range. However, since the magnitudes of the saving and investment semi-elasticities

\footnotetext{
${ }^{13}$ That coordination is not needed under complete profit taxation is also established in Prop. 2 of Huizinga and Nielsen (2002).
} 
are not known and the foreign ownership share is only imperfectly estimated, any firm conclusion as to whether the restoration of saving taxation is preferable seems precluded.

Our second reason for withholding a firm judgement on the desirability of restoring savings taxation in the EU has to do with the fact that our model offers only a first step towards modeling the issue. In fact, we have opted for a two-period model and we have suppressed taxes other than on capital income to bring out the underlying ambiguity in the simplest possible way. A full examination of the issue will have to be of a quantitative nature, and therefore a fully-fledged computable dynamic equilibrium model along the lines of Mendoza and Tesar (2003) or Klein et al. (2003) would be a welcome extension of the present paper. Once foreign ownership of firms plus pure profits are introduced in multi-country versions of such models, it may be possible to shed more light on whether we should expect a loss of residence-based capital income taxes to lower welfare or not.

In a more realistic setting, labor income and consumption taxation would be allowed for. These taxes would probably take the brunt of the burden of financing government expenditures, alleviating the pressure on capital income taxes in our model. Exactly how high personal capital and corporate income taxes would be set hinges crucially on whether the government can commit to its policy choice and for how long. In our twoperiod model, we have assumed full commitment powers on the part of governments, but in a multi-period setting the time consistency issue must be addressed head-on.

\section{Conclusions}

At present, most countries de jure levy residence-based personal capital income taxes as well as source-based corporate income (and withholding) taxes. The former fall on saving, while the latter fall on investment and supranormal profits. Residence-based capital income taxes, however, are increasingly difficult to enforce, as international capital markets become more integrated. The evasion of residence-based capital income taxes potentially leads to the effective disappearance of the taxation of saving. 
The central Proposition of this paper indicates that such an elimination paradoxically may improve welfare, as it may bring the saving-investment tax wedge emerging from non-cooperative tax policy closer to the optimal tax wedge that arises under full coordination. This will occur if preferences for public goods are relatively weak. The result also presupposes the existence of cross-border profit flows as brought about by foreign ownership of firms and limitations on the taxation of pure profits. At the very least, the loss of saving taxation could well be considerably less harmful than often perceived. Translated into the language used in tax reform debates, a transition from the present combination of personal capital income taxation and corporate income taxation (with deduction of interest on debt) to, say, a comprehensive business income tax (CBIT), where capital income is solely taxed at the level of the firm and without deduction of interest on debt, might not be such a bad thing after all. ${ }^{14}$ In this respect, one can note that preferences for public goods, at least at the level of public administrations, are not etched in stone. Hence, it is possible that 'preference drift' towards higher preferences for public goods can explain an increased willingness at the international level to contemplate effective cooperation to recover the taxation of savings.

Analogous to the discussion of this paper, it is feasible to consider the loss of the investment tax instrument rather than the savings tax instrument. In fact, several scholars, among them Mintz and Tulkens (1996), have advocated an international switch to exclusively residence-based capital income taxes. Using the techniques of this paper, it is possible to show that the elimination of investment taxes can improve welfare, if preferences for public goods are rather weak. In this instance, investment taxes are used primarily to redistribute income internationally rather than to finance public goods. International income redistribution through investment taxation, however, distorts capital investment, and hence is best eliminated. On the other hand, if preferences for public goods are strong, then eliminating investment taxation is bound to reduce welfare.

\footnotetext{
${ }^{14}$ For a discussion of the CBIT proposal and competing ways of taxing capital income in the open economy, see U.S. Department of the Treasury (1992) and Cnossen (1996).
} 


\section{Appendix}

Table 1. Direct and portfolio investment liabilities as shares of GDP in the EU, 1998.

$\begin{array}{lcc}\text { Country } & \text { Direct inv. liabilities } & \text { Portfolio inv. liabilities } \\ \text { Austria } & 0.13 & 0.07 \\ \text { Belgium-Lux. } & 0.77 & 0.08 \\ \text { Germany } & 0.04 & 0.09 \\ \text { Denmark } & 0.17 & 0.12 \\ \text { Spain } & 0.22 & 0.13 \\ \text { Finland } & 0.15 & 0.63 \\ \text { France } & 0.16 & 0.20 \\ \text { United Kingdom } & 0.24 & 0.49 \\ \text { Italy } & 0.09 & 0.06 \\ \text { Netherland } & 0.36 & 0.62 \\ \text { Portugal } & 0.20 & 0.18 \\ \text { Sweden } & 0.24 & 0.42 \\ \text { EU-average } & 0.14 & 0.16\end{array}$

Sources: International Financial Statistics (Balance of Payments), World Bank.

Note: The entries show the stocks of investment liabilities relative to GDP. The data for Germany and Netherlands are for 1997. 
Table 2. Total tax revenue as percentage of GDP in the EU, 1975-2000.

$\begin{array}{lcccccc}\text { Country } & 1975 & 1980 & 1985 & 1990 & 1995 & 2000 \\ \text { Austria } & 37.5 & 39.8 & 41.9 & 40.5 & 41.6 & 43.3 \\ \text { Belgium } & 40.2 & 42.4 & 45.6 & 43.2 & 44.6 & 45.7 \\ \text { Denmark } & 40.0 & 44.0 & 47.4 & 47.1 & 49.4 & 49.5 \\ \text { Finland } & 36.6 & 36.1 & 39.6 & 44.6 & 45.1 & 47.3 \\ \text { France } & 35.9 & 40.6 & 43.8 & 43.0 & 44.0 & 45.2 \\ \text { Germany } & 32.6 & 34.6 & 34.3 & 32.9 & 38.2 & 37.7 \\ \text { Greece } & 21.8 & 24.2 & 28.6 & 29.3 & 32.4 & 37.6 \\ \text { Ireland } & 29.1 & 31.4 & 35.1 & 33.5 & 32.8 & 31.2 \\ \text { Italy } & 26.1 & 30.4 & 34.4 & 38.9 & 41.2 & 41.9 \\ \text { Luxembourg } & 37.5 & 40.8 & 45.1 & 40.8 & 42.4 & 40.4 \\ \text { Netherlands } & 41.6 & 43.6 & 42.6 & 43.0 & 42.0 & 41.1 \\ \text { Portugal } & 20.8 & 24.1 & 26.6 & 29.2 & 32.5 & 34.3 \\ \text { Spain } & 18.8 & 23.1 & 27.8 & 33.2 & 32.8 & 35.2 \\ \text { Sweden } & 41.0 & 46.1 & 47.0 & 51.9 & 48.5 & 54.0 \\ \text { UK } & 35.3 & 35.2 & 37.7 & 36.8 & 34.8 & 37.3 \\ \text { EU-15 } & 33.0 & 35.8 & 38.5 & 39.2 & 40.1 & 41.5\end{array}$

Source: OECD Revenue Statistics. 


\section{References}

[1] Bucovetsky, Sam, 1991, Asymmetric tax competition, Journal of Urban Economics $30,167-181$.

[2] Bucovetsky, Sam and John Douglas Wilson, 1991, Tax competition with two tax instruments, Regional Science and Urban Economics 21, 333-350.

[3] Cnossen, Sijbren, 1996, Company taxes in the European Union: criteria and options for reform, Fiscal Studies 17(4), 67-97.

[4] Frenkel, Jacob, Assaf Razin and Efraim Sadka, 1991, International taxation in an integrated world, Cambridge, MA.

[5] Gordon, Roger H., 1986, Taxation of investment and savings in a world economy, American Economic Review 96, 1086-1102.

[6] Huizinga, Harry P. and Søren Bo Nielsen, 1997, Capital income and profit taxation with foreign ownership of firms, Journal of International Economics 42, 149-165.

[7] Huizinga, Harry P. and Søren Bo Nielsen, 2002, The coordination of capital income and profit taxation with cross-ownership of firms, Regional Science and Urban Economics $32,1-26$.

[8] Huizinga, Harry P. and Søren Bo Nielsen, 2003, Withholding taxes or information exchange: the taxation of interest flows, Journal of Public Economics 87, 39-72.

[9] Keen, Michael, 1993, The welfare economics of tax coordination in the European Community, Fiscal Studies 14, 15-35.

[10] Keen, Michael, and Jenny E. Ligthart, 2002, Incentives and information exchange in international taxation, mimeo, Fiscal Affairs Department, International Monetary Fund, November 5, 2002. 
[11] Klein, Paul, Vincenzo Quadrini and Jose-Victor Rios-Rull, 2003, Optimal timeconsistent taxation with international mobility of capital, mimeo, Department of Economics, University of Western Ontario, October 23, 2003.

[12] Mendoza, Enrique G. and Linda L. Tesar, 2003, A quantitative analysis of tax competition v. tax coordination under perfect capital mobility, NBER Working Paper 9746.

[13] Mintz, Jack and Henry Tulkens, 1996, Optimality properties of alternative systems of taxation of foreign capital income, Journal of Public Economics, 60, 373-401.

[14] OECD, 1991, Taxing profits in the global economy, Paris.

[15] Razin, Assaf and Efraim Sadka, 1991, International tax competition and gains from tax harmonization, Economics Letters 37, 69-76.

[16] Ruding Report, 1992, Report of the committee of independent experts on company taxation, Brussels.

[17] US Department of the Treasury, 1992, Integration of the individual and corporate tax systems: taxing business income once, US Government Printing Office, Washington, DC. 